\title{
Association between cardiac enzyme elevation and clinical prognosis of neurosurgical and neurocritically ill patients
}

\author{
Jung Hwa Lee
}

Department of Neurology

\section{Yun Im Lee}

Department of Critical Care Medicine

Joonghyun Ahn

Statistic and data center, Clinical Research Institute

Jeong-Am Ryu ( $\sim$ lamyud.ryu@samsung.com )

Samsung Medical Center https://orcid.org/0000-0003-1705-848X

\section{Research}

Keywords: Cardiac enzyme, prognosis, neurosurgery, intensive care unit

Posted Date: January 7th, 2021

DOI: https://doi.org/10.21203/rs.3.rs-127682/v2

License: (c) (i) This work is licensed under a Creative Commons Attribution 4.0 International License. Read Full License 


\section{Abstract \\ Background}

To investigate whether cardiac troponin (cTn) elevation is associated with in-hospital mortality and major adverse cardiac events (MACEs) in neurosurgical and neurocritically ill patients.

\section{Methods}

Among neurosurgical patients admitted to the intensive care unit (ICU) in a tertiary hospital from January 2013 to December 2019, those whose serum cTnl levels were obtained within 7 days after ICU admission were included. Propensity score matching was used. Each patient with cTnl elevation was matched to one of control patients. The primary endpoint was in-hospital mortality and the secondary outcome was MACE.

\section{Results}

cTnl elevation was shown in $702(11.7 \%)$ of 6,004 patients. After propensity score matching, 617 pairs of data were generated by 1:1 individual matching without replacement. Rates of in-hospital mortality in the overall population and the propensity score-matched population were higher for patients with cTnl elevation than for those without cTnl elevation ( $p<0.001$ and $p=0.003$, respectively). In addition, MACEs were more common in patients with cTnl elevation than in those without cTnl elevation in the overall population and the propensity score-matched population (both $p<0.001$ ). In multivariable analysis of overall and propensity score-matched population, cTnl elevation were associated with in-hospital mortality (adjusted odds ratio [OR]: 2.78, 95\% confidence interval [CI]: 1.95-3.95 and adjusted OR: 1.77, $95 \% \mathrm{Cl}: 1.20-2.62$, respectively). In addition, cTnl elevation were associated with MACE (adjusted OR: $3.75,95 \% \mathrm{Cl}: 2.43-5.78$ and adjusted OR: $4.04,95 \% \mathrm{Cl}: 2.24-7.29$, respectively). In survival analysis, the mortality rate of patients with cTnl elevation was significantly higher than in those without cTnl elevation for the propensity score-matched population $(28.8 \%$ vs. $19.3 \%$, log-rank test, $p<0.001)$.

\section{Conclusions}

In this study, cTnl elevation was associated with in-hospital mortality and MACEs in neurosurgical and neurocritically ill patients.

\section{Background}

Perioperative myocardial injury is associated with major adverse cardiac events (MACEs) and clinical prognosis of patients with non-cardiac or non-vascular surgeries [1]. Many surgical patients experience MACEs during the perioperative period and the first year after surgery [1-4]. Especially, postoperative 
cardiac troponin (cTn) elevation is important to predict prognosis of these surgical patients [1]. In addition, cTn elevation is associated with increased mortality and hospitalization in critically ill patients [5]. Regardless of the associated cardiovascular disease, cTn is a specific marker of myocardial injury and a predictor of prognosis [6-8].

Most morbidity and mortality of neurosurgical patients might be due to neurosurgical or neurocritically illness, although cardiac injury might also contribute to their poor clinical prognosis [9-11]. cTn elevation is also associated with prognosis of neurocritically ill patients with intracerebral hemorrhage or subarachnoid hemorrhage $[9,11-13]$.

A limited number of studies have reported that clinical outcomes of neurosurgical and neurocritically ill patients are associated with cTn elevation $[9,10,13]$. Therefore, the objective of this study was to investigate whether cTn elevation might be associated with in-hospital mortality and MACEs in patients admitted to neurosurgical intensive care unit (ICU). In addition, we evaluated whether cTn elevation per se was associated with poor prognosis when severity and factors other than cTn elevation were controlled by propensity score matching.

\section{Methods}

\section{Study population and design}

This was a retrospective, single-center, observational study. Patients who were admitted to the neurosurgical ICU in a tertiary referral hospital (Samsung Medical Center, Seoul, Republic of Korea) from January 2013 to December 2019 were eligible. This study was approved by the Institutional Review Board of Samsung Medical Center (approval number: SMC 2020-09-082). Included criteria were: (1) patients who were hospitalized in the neurosurgical ICU due to postoperative management or neurocritical illness, and (2) those whose serum cTnl levels were obtained within seven days after ICU admission. Exclusion criteria were: (1) those with insufficient medical records, (2) those who had 'do not resuscitation' order, (3) those who were admitted to departments other than neurosurgery, and (4) those who were transferred to other hospitals or with unknown prognoses (Fig. 1).

\section{Definitions and endpoints}

In this study, baseline characteristics such as comorbidities, ICU management, and laboratory data were collected retrospectively using Clinical Data Warehouse. Our center constructed the "Clinical Data Warehouse Darwin-C" designed for investigators to search and retrieve de-identified medical records from electronic archives. It contains data pertaining to more than four million patients. Clinical and laboratory data were extracted from the Clinical Data Warehouse Darwin-C after finalizing the patient list in this study. Risk of surgery was defined according to the 2014 European Society of Cardiology/European Society of Anesthesiology (ESC/ESA) guidelines [14]. Perioperative management of patients followed institutional protocols based on current guidelines $[6,14]$. According to the institutional guideline, 
perioperative cTnl was measured for patients with more than moderate risk or undergoing moderate- to high-risk surgeries [14]. It was also measured at the discretion of attending clinician for patients with mild risks $[6,14]$. An automated analyzer (Advia Centaur XP; Siemens Healthcare Diagnostics, Erlangen, Germany) with a highly sensitive immunoassay was used for cTnI measurement. The lowest limit of detection was $6 \mathrm{ng} / \mathrm{L}$. In this study, cTnl elevation was defined as an increase in CTnl above $0.06 \mu \mathrm{g} / \mathrm{L}$ within 7 days after ICU admission [15]. Acute Physiology and Chronic Health Evaluation (APACHE) II score was calculated based on the worst value recorded during the initial $24 \mathrm{~h}$ in the ICU admission [16, 17]. If the patient was intubated, the verbal score of Glasgow Coma Scale (GCS) was estimated using eye and motor scores as reported previously [18]. MACEs were defined as non-fatal cardiac arrest, emergent coronary revascularization, acute coronary syndrome, stroke, congestive heart failure, atrial fibrillation (new onset or destabilization of pre-existing atrial fibrillation), major arrhythmia, cardiovascular death, and rehospitalization for cardiovascular reasons [1]. The primary endpoint was in-hospital mortality and the secondary outcome was MACE.

\section{Statistical analyses}

All data are presented as means \pm standard deviations for continuous variables and frequencies and proportions for categorical variables. Data were compared using Student's $t$-test for continuous variables and Chi-square test or Fisher's exact test for categorical variables. Propensity score matching was used to control the selection bias and the confounding factor detected in this observational study. Each patient with cTnl elevation was matched to one control patient with the nearest neighbor matching within calipers determined by the propensity score. A caliper width of 0.2 of the standard deviation of the logit of the propensity score was used for the matching [19]. To determine the effectiveness of propensity score matching for controlling the differences between patients with and without cTnl elevation, standardized mean differences (SMDs) were calculated for each variable before and after matching. SMDs less than $10 \%$ indicated successful propensity scores matching and balancing between the two groups. To evaluate whether there is a difference in in-hospital mortality and MACEs according to the cTnl elevation, we performed multiple logistic regression with stepwise variable selection in the overall and matched population. In the overall population, we tried to obtain the result of correcting confounding through regression adjustment, and in the matching dataset, we perform doubly robust estimation to additionally correct the bias that still exits after propensity score matching. The variables included in the multiple analyses were age, sex, comorbidities, cause of ICU admission, utilization of organ support modalities, including mechanical ventilators, continuous renal replacement therapy and vasopressors, ICP monitoring devices, hyperosmolar therapy, GCS, and APACHE II score on ICU admission. Cumulative mortality was calculated by Kaplan-Meier estimate and compared using a log-rank test. All tests were two-sided and $p$ values less than 0.05 were considered statistically significant. All statistical analyses were performed with R Statistical Software (version 4.0.2; R Foundation for Statistical Computing, Vienna, Austria).

\section{Results}




\section{Baseline characteristics}

A total of 12,743 patients were admitted to the neurosurgical ICU during the study period and 6,004 patients were included in the final analysis. In the overall study population, cTnl elevation was shown in $702(11.7 \%$ ) patients (Fig. 1). The mean age of all patients was $55.8 \pm 15.6$ years. There were 2,698 (44.9\%) male patients. Malignancy (50.5\%) and hypertension (34.8) were the most common comorbidities. Elective vascular surgery $(37.1 \%)$ and brain tumors $(36.0 \%)$ were the most common reasons for ICU admission (Table 1). In the overall population, there were significantly differences for variables of baseline characteristics between the two groups except for current smoking and the use of mannitol (Table 1). The mean value of maximum cTnl level was higher in the cTnl elevation group than in the normal cTnl group $(5.1 \pm 34.3 \mu \mathrm{g} / \mathrm{L}$ vs. $0 \pm 0 \mu \mathrm{g} / \mathrm{L}, p<0.001)$. After propensity score matching, 617 pairs of data were generated by 1:1 individual matching without replacement. No significant imbalance was found in baseline characteristics between matched pairs (Table 1). 
Table 1

Baseline characteristics of study population

Overall study population

$\begin{array}{llllllll}\begin{array}{l}\text { No } \\ \text { elevation }\end{array} & \text { Elevation } & P & \text { SMD } & \begin{array}{l}\text { No } \\ \text { elevation } \\ (n=617)\end{array} & \begin{array}{l}\text { Elevation } \\ (n=617)\end{array} & \begin{array}{l}P \\ \text { value }\end{array} & \text { SMD } \\ \begin{array}{l}(n=702) \\ 5302)\end{array} & & & & & & \\ \end{array}$

Propensity score-matched population
Patient

demographics

Age (year)

Sex, male

$54.94 \pm$ 15.31

2341

(44.2)
$62.05 \pm<$

15.97

357

(50.9)

Comorbidities

Malignancy

2724

(51.4)

306

(43.6)

$<\quad 0.156$

291

(47.2)

$60.89 \pm$

$61.92 \pm$

$0.248 \quad 0.066$

15.51

15.91

319

(51.7)

308

(49.9)

$0.569 \quad 0.036$

Hypertension

1751

(33.0)

339
$(48.3)$

¿ 001

$0.315 \quad 293$

(47.5)

$0.208 \quad 114$

131

(11.3)

(18.7)

0.001

(18.5)

$0.325 \quad 58(9.4)$

0.001

disease

168 (3.2)

Cardiovascular

disease

Chronic liver

$103(1.9)$

81 (11.5)

0.001

77 (11.0)

0.001

$0.374 \quad 52(8.4)$

290

(47.0)

$0.999 \quad 0.003$

disease

$102(1.9)$

$28(4.0)$

0.001

$0.122 \quad 22(3.6)$

302

(48.9)

$0.649 \quad 0.029$

Behavioral risk

factors

Current

alcohol

consumption

1285

(24.2)
144

(20.5)
0.033

0.089

141

(22.9)

116

(18.8)

$67(10.9) \quad 0.450 \quad 0.048$

$\begin{array}{lll}57(9.2) & 0.688 & 0.029\end{array}$

$24(3.9) \quad 0.881 \quad 0.017$

$0.942 \quad 0.008$ 


\begin{tabular}{|c|c|c|c|c|c|c|c|c|}
\hline \multirow[b]{2}{*}{$\begin{array}{l}\text { Current } \\
\text { smoking }\end{array}$} & \multicolumn{4}{|c|}{ Overall study population } & \multicolumn{4}{|c|}{ Propensity score-matched population } \\
\hline & $\begin{array}{l}586 \\
(11.1)\end{array}$ & $81(11.5)$ & 0.748 & 0.015 & $83(13.5)$ & $76(12.3)$ & 0.610 & 0.034 \\
\hline $\begin{array}{l}\text { Cause of ICU } \\
\text { admission }\end{array}$ & & & $<.001$ & 1.175 & & & 0.935 & 0.098 \\
\hline Brain tumor & $\begin{array}{l}2006 \\
(37.8)\end{array}$ & $\begin{array}{l}155 \\
(22.1)\end{array}$ & & & $\begin{array}{l}160 \\
(25.9)\end{array}$ & $\begin{array}{l}154 \\
(25.0)\end{array}$ & & \\
\hline $\begin{array}{l}\text { Elective } \\
\text { vascular } \\
\text { surgery }\end{array}$ & $\begin{array}{l}2162 \\
(40.8)\end{array}$ & $68(9.7)$ & & & $67(10.9)$ & $68(11.0)$ & & \\
\hline $\begin{array}{l}\text { Intracerebral } \\
\text { hemorrhage }\end{array}$ & $265(5.0)$ & $\begin{array}{l}129 \\
(18.4)\end{array}$ & & & $\begin{array}{l}121 \\
(19.6)\end{array}$ & $\begin{array}{l}105 \\
(17.0)\end{array}$ & & \\
\hline $\begin{array}{l}\text { Traumatic } \\
\text { brain injury }\end{array}$ & $247(4.7)$ & $\begin{array}{l}129 \\
(18.4)\end{array}$ & & & $\begin{array}{l}105 \\
(17.0)\end{array}$ & $\begin{array}{l}106 \\
(17.2)\end{array}$ & & \\
\hline $\begin{array}{l}\text { Subarachnoid } \\
\text { hemorrhage }\end{array}$ & $211(4.0)$ & $\begin{array}{l}135 \\
(19.2)\end{array}$ & & & $\begin{array}{l}101 \\
(16.4)\end{array}$ & $\begin{array}{l}110 \\
(17.8)\end{array}$ & & \\
\hline Spinal surgery & $217(4.1)$ & $25(3.6)$ & & & $21(3.4)$ & $24(3.9)$ & & \\
\hline $\begin{array}{l}\text { Central } \\
\text { nervous } \\
\text { system } \\
\text { infection }\end{array}$ & $41(0.8)$ & $10(1.4)$ & & & $9(1.5)$ & $10(1.6)$ & & \\
\hline $\begin{array}{l}\text { Cerebral } \\
\text { infarction }\end{array}$ & $33(0.6)$ & $14(2.0)$ & & & $14(2.3)$ & $14(2.3)$ & & \\
\hline Others & $20(2.3)$ & $37(5.3)$ & & & $19(3.1)$ & $26(4.2)$ & & \\
\hline $\begin{array}{l}\text { APACHE II } \\
\text { score on ICU } \\
\text { admission }\end{array}$ & $\begin{array}{l}3.26 \pm \\
4.35\end{array}$ & $\begin{array}{l}7.87 \pm \\
8.03\end{array}$ & $\begin{array}{l}< \\
0.001\end{array}$ & 0.713 & $\begin{array}{l}6.72 \pm \\
6.58\end{array}$ & $\begin{array}{l}7.06 \pm \\
7.50\end{array}$ & 0.399 & 0.048 \\
\hline $\begin{array}{l}\text { Glasgow coma } \\
\text { scale on ICU } \\
\text { admission }\end{array}$ & $\begin{array}{l}14.60 \pm \\
1.61\end{array}$ & $\begin{array}{l}12.02 \pm \\
4.33\end{array}$ & $\begin{array}{l}< \\
0.001\end{array}$ & 0.79 & $\begin{array}{l}12.79 \pm \\
3.63\end{array}$ & $\begin{array}{l}12.47 \pm \\
4.05\end{array}$ & 0.151 & 0.082 \\
\hline $\begin{array}{l}\text { ICU } \\
\text { management }\end{array}$ & & & & & & & & \\
\hline
\end{tabular}

Data are presented as numbers (\%) or means \pm standard deviations

*Some patients received more than one hyperosmolar agent

${ }^{\dagger}$ Variables are not retained in propensity score matching

APACHE I/ Acute Physiology and Chronic Health Evaluation; ICP intracranial pressure, ICU intensive care unit; $S M D$ standardized mean difference 


\begin{tabular}{|c|c|c|c|c|c|c|c|c|}
\hline \multirow[b]{2}{*}{$\begin{array}{l}\text { Use of } \\
\text { vasopressors }\end{array}$} & \multicolumn{4}{|c|}{ Overall study population } & \multicolumn{4}{|c|}{ Propensity score-matched population } \\
\hline & $127(2.4)$ & $88(12.5)$ & $<.001$ & 0.393 & $69(11.2)$ & $71(11.5)$ & 0.928 & 0.010 \\
\hline $\begin{array}{l}\text { Mechanical } \\
\text { ventilation }\end{array}$ & $\begin{array}{l}842 \\
(15.9)\end{array}$ & $\begin{array}{l}437 \\
(62.3)\end{array}$ & $<001$ & 1.080 & $\begin{array}{l}358 \\
(58.0)\end{array}$ & $\begin{array}{l}352 \\
(57.1)\end{array}$ & 0.773 & 0.020 \\
\hline $\begin{array}{l}\text { Continuous } \\
\text { renal } \\
\text { replacement } \\
\text { therapy }\end{array}$ & $13(0.2)$ & $44(6.3)$ & $<.001$ & 0.344 & $12(1.9)$ & $21(3.4)$ & 0.158 & 0.091 \\
\hline ICP monitoring & $403(7.6)$ & $\begin{array}{l}143 \\
(20.4)\end{array}$ & $<.001$ & 0.375 & $\begin{array}{l}133 \\
(21.6)\end{array}$ & $\begin{array}{l}123 \\
(19.9)\end{array}$ & 0.527 & 0.040 \\
\hline $\begin{array}{l}\text { Use of } \\
\text { mannitol }^{*}\end{array}$ & $\begin{array}{l}2304 \\
(43.5)\end{array}$ & $\begin{array}{l}295 \\
(42.0)\end{array}$ & 0.497 & 0.029 & $\begin{array}{l}270 \\
(43.8)\end{array}$ & $\begin{array}{l}268 \\
(43.4)\end{array}$ & 0.954 & 0.007 \\
\hline $\begin{array}{l}\text { Use of } \\
\text { glycerin }\end{array}$ & $\begin{array}{l}549 \\
(10.4)\end{array}$ & $\begin{array}{l}226 \\
(32.2)\end{array}$ & $\stackrel{<}{0.001}$ & 0.554 & $\begin{array}{l}200 \\
(32.4)\end{array}$ & $\begin{array}{l}189 \\
(30.6)\end{array}$ & 0.540 & 0.038 \\
\hline \multicolumn{9}{|l|}{$\begin{array}{l}\text { Clinical } \\
\text { outcomes }^{\dagger}\end{array}$} \\
\hline $\begin{array}{l}\text { In-hospital } \\
\text { mortality }\end{array}$ & $176(3.3)$ & $\begin{array}{l}208 \\
(29.6)\end{array}$ & $\begin{array}{l}< \\
0.001\end{array}$ & & $\begin{array}{l}115 \\
(18.6)\end{array}$ & $\begin{array}{l}159 \\
(25.8)\end{array}$ & 0.003 & \\
\hline $\begin{array}{l}\text { 28-day } \\
\text { mortality }\end{array}$ & $161(3.0)$ & $\begin{array}{l}206 \\
(29.3)\end{array}$ & $<.001$ & & $\begin{array}{l}104 \\
(16.9)\end{array}$ & $\begin{array}{l}159 \\
(25.8)\end{array}$ & 0.000 & \\
\hline ICU mortality & $100(1.9)$ & $\begin{array}{l}150 \\
(21.4)\end{array}$ & $\begin{array}{l}< \\
0.001\end{array}$ & & $77(12.5)$ & $\begin{array}{l}109 \\
(17.7)\end{array}$ & 0.014 & \\
\hline $\begin{array}{l}\text { ICU length of } \\
\text { stay (day) }\end{array}$ & $\begin{array}{l}59.6 \pm \\
332.7\end{array}$ & $\begin{array}{l}127.6 \pm \\
185.7\end{array}$ & $<.001$ & & $\begin{array}{l}171.0 \pm \\
901.3\end{array}$ & $\begin{array}{l}124.5 \pm \\
181.4\end{array}$ & 0.210 & \\
\hline $\begin{array}{l}\text { Hospital } \\
\text { length of stay } \\
\text { (day) }\end{array}$ & $\begin{array}{l}23.5 \pm \\
93.7\end{array}$ & $\begin{array}{l}46.0 \pm \\
222.3\end{array}$ & 0.008 & & $\begin{array}{l}58.4 \pm \\
251.5\end{array}$ & $\begin{array}{l}34.0 \pm \\
43.0\end{array}$ & 0.018 & \\
\hline $\begin{array}{l}\text { Major adverse } \\
\text { cardiac events }\end{array}$ & & & $<.001$ & & & & $<.001$ & \\
\hline $\begin{array}{l}\text { New onset } \\
\text { arrhythmia }\end{array}$ & $55(1.0)$ & $22(3.1)$ & & & $13(2.1)$ & $19(3.1)$ & & \\
\hline
\end{tabular}

Data are presented as numbers (\%) or means \pm standard deviations

*Some patients received more than one hyperosmolar agent

${ }^{\dagger}$ Variables are not retained in propensity score matching

APACHE I/ Acute Physiology and Chronic Health Evaluation; ICP intracranial pressure, ICU intensive care unit; $S M D$ standardized mean difference 


\begin{tabular}{|c|c|c|c|c|}
\hline & \multicolumn{2}{|c|}{ Overall study population } & \multicolumn{2}{|c|}{ Propensity score-matched population } \\
\hline Heart failure & $3(0.1)$ & $14(2.0)$ & $1(0.2)$ & $11(1.8)$ \\
\hline $\begin{array}{l}\text { Acute coronary } \\
\text { syndrome }\end{array}$ & $1(0.02)$ & $12(1.7)$ & $0(0)$ & $9(1.5)$ \\
\hline Cardiac arrest & $1(0.02)$ & $5(0.7)$ & $1(0.2)$ & $5(0.8)$ \\
\hline $\begin{array}{l}\text { Cardiovascular } \\
\text { death }\end{array}$ & $0(0)$ & $15(2.1)$ & $0(0)$ & $11(1.8)$ \\
\hline \multicolumn{5}{|c|}{ Data are presented as numbers $(\%)$ or means \pm standard deviations } \\
\hline \multicolumn{5}{|c|}{ *Some patients received more than one hyperosmolar agent } \\
\hline \multicolumn{5}{|c|}{${ }^{\dagger}$ Variables are not retained in propensity score matching } \\
\hline \multicolumn{5}{|c|}{$\begin{array}{l}A P A C H E \text { II Acute Physiology and Chronic Health Evaluation; ICP intracranial pressure, ICU intensive } \\
\text { care unit; } S M D \text { standardized mean difference }\end{array}$} \\
\hline
\end{tabular}

\section{Clinical outcomes}

In the overall study population, rates of in-hospital mortality and ICU mortality were higher in patients with cTnl elevation than in those without cTnl elevation ( $29.6 \%$ vs. $3.3 \%$ and $21.4 \%$ vs. $1.9 \%$, both $p<0.001)$ (Table 1). Lengths of stay in the ICU and hospital were prolonged in patients with cTnl elevation than in those without cTnl elevation ( $p<0.001$ and $p=0.008$, respectively). Clinical outcomes in the propensity score-matched population were similar to those of the entire population. In the propensity score-matched population, rates of in-hospital mortality and ICU mortality were also higher in the elevated cTnI group than in the normal cTnl group ( $25.8 \%$ vs. $18.6 \%$ and $17.7 \%$ vs. $12.5, p=0.003$ and $p=0.014$, respectively). MACEs were more common in patients with cTnl elevation than in those without cTnl elevation in the overall population and the propensity score-matched population $(9.7 \%$ vs. $1.1 \%$ and $8.9 \%$ vs. $2.4 \%$, both $p$ $<0.001$ ) (Table 1).

In multivariable analysis of the overall and propensity score-matched population, cTnl elevation were associated with in-hospital mortality (adjusted odds ratio [OR]: 2.78, 95\% confidence interval [Cl]: 1.953.95 and adjusted OR: $1.77,95 \% \mathrm{Cl}: 1.20-2.62$, respectively). In addition, cTnl elevation were associated with MACE (adjusted OR: 3.75, 95\% Cl: 2.43-5.78 and adjusted OR: 4.04, 95\% Cl: 2.24-7.29, respectively) (Table 2). 
Table 2

The relationship between elevated cardiac troponin I (cTnI) and clinical outcomes of the overall and propensity score-matched population

\begin{tabular}{llc} 
cTnl elevation within 7 days & *Adjusted odds ratio $(95 \% \mathrm{Cl})$ & $\boldsymbol{P}$ value \\
\hline In-hospital mortality & & $<0.001$ \\
\hline Overall population & $2.78(1.95-3.95)$ & 0.004 \\
\hline Propensity score-matched population & $1.77(1.20-2.62)$ & $<0.001$ \\
\hline Major adverse cardiac events & & $<0.001$ \\
\hline Overall population & $3.75(2.43-5.78)$ & \\
\hline Propensity score-matched population & $4.04(2.24-7.29)$ &
\end{tabular}

* Adjusted for age, sex, comorbidities, cause of ICU admission, utilization of organ support modalities, use of invasive ICP monitoring device, hyperosmolar therapy, and APACHE II score on ICU admission

$\mathrm{Cl}$ confidence interval; $A P A C H E$ Acute Physiology and Chronic Health Evaluation; ICP intracranial pressure; ICU intensive care unit

In survival analysis, the mortality rate of patients with cTnl elevation was significantly higher than that of patients without cTnl elevation in the propensity score-matched population $(28.8 \%$ vs. $19.3 \%$, log-rank test, $p<0.001$ ) (Fig. 2).

\section{Discussion}

In this study, we investigated whether cTn elevation was associated with mortality and MACEs in patient admitted to neurosurgical ICU. Major findings of this study were as follows. First, elevated cTnl level was shown in about one-tenth of neurosurgical patients in the overall population. Second, rates of in-hospital mortality and ICU mortality were higher in patients with cTnl elevation than in those without cTnI elevation in the overall study population and the propensity score-matched population. The length of hospitalization was also prolonged in patients with cTnl elevation than in those without cTnl elevation in both populations Finally, multivariable analysis revealed that cTnl elevation were associated with inhospital mortality and MACE in overall and propensity score-matched population.

cTn is a regulatory protein that can lead to myocardial contraction by controlling calcium-mediated interaction with actin and myosin $[5,20]$. Destroyed cardiomyocytes can release cTn into the blood which can be detected using a commercially available immunoassay [5]. Postoperative myocardial injury is an independent predictor of cardiovascular complications and mortality within 30 days and one year in patients undergoing orthopedic or abdominal surgeries [1]. Especially, cTn elevation is associated with worse cardiac outcomes after major surgeries [21]. In addition, elevated cTn measurements among critically ill patients are associated with increased mortality and ICU length of stay [5]. 
In patients with subarachnoid hemorrhage, electrocardiographic abnormalities, including prolongation of QT interval and repolarization abnormalities, are commonly detected $[9,12]$. Especially, cTn elevation has been found in one-third of patients with subarachnoid hemorrhage known to be associated with increased mortality $[9,13]$. cTn elevation is also associated with mortality in patients with surgically treated intracerebral hemorrhage and traumatic brain injury $[9,22]$. Under stressful conditions such as acute brain injury, stimulation of the hypothalamic paraventricular nucleus as the main control center of the hypothalamic-pituitary-adrenal axis can activate sympathetic output and lead to electrocardiographic abnormalities, arrhythmia, and myocardial injury [23]. In addition, activation of this axis after acute brain injury can cause a significant increase in catecholamines. The catecholamine surge hypothesis is the most widely accepted mechanism of brain-heart interaction [23]. Recent histological studies have shown that catecholamine-mediated myocardial injury may be a major pathophysiology of neurocritical illness $[9-11,24]$. Therefore, cardiac injury could be accompanied by neurosurgical or neurocritical illness. It is known to be associated with clinical prognosis [9-11, 22, 24].

Neurosurgical patients with severe brain injury are more likely to develop cardiac injury and MACEs compared to those with benign diseases. Therefore, it is not easy to determine whether elevated cTn itself is associated with a poor prognosis or neurosurgical patients with elevated cTn will show poor prognosis because of their neurocritical illness. Therefore, a propensity score matching method was used to adjust for this confounder in this study. In brief, cTnl elevation was significantly associated with poor clinical outcomes of neurosurgical and neurocritically ill patients. Finally, the majority of morbidity and mortality could be arising from neurocritical illness, although other studies have suggested that cardiac injury might also be a contributing factor [9-11].

This study has several limitations. First, this was a retrospective review of medical records and data extracted from Clinical Data Warehouse. The nonrandomized nature of registry data might have resulted in a selection bias. Second, laboratory tests including cTnl levels were protocol-based for patients with perioperative neurosurgery. They were performed occasionally by non-protocol methods for neurocritically ill patients without neurosurgery. Third, the pathophysiology of acute coronary syndrome could not be determined for a few patients. Cardiac catheterization was not performed in these sick patients because intrahospital transport was impossible due to severe illness. Finally, the distribution of neurosurgical diseases differed from that of the general neurosurgical ICU and the proportion of patients with brain tumors was particularly high.

\section{Conclusions}

In this study, cTnl elevation was associated with in-hospital mortality and cardiac complications in neurosurgical and neurocritically ill patients. In addition, the length of hospitalization was prolonged for patients with cTnl elevation than that for those without cTnl elevation. Finally, perioperative or neurocritical illness-associated cardiac injury could be associated with clinical outcomes of neurosurgical and neurocritically ill patients. 


\section{Declarations}

\section{Ethics approval and consent to participate}

This study was approved by the Institutional Review Board of Samsung Medical Center (approval number: SMC 2020-09-082). Patients' records were reviewed and published according to the Declaration of Helsinki. The requirement of informed consent was waived due to the retrospective nature of this study.

\section{Consent for publication}

Not applicable. This study did not contain individual or personal data in any form (including individual details, images, or videos).

\section{Availability of data and materials}

Our data are available on Harvard Dataverse Network (http://dx.doi.org/10.7910/DVN/9HU70P).

\section{Competing interests}

The authors declare that they have no competing interests.

\section{Funding}

Not applicable.

\section{Authors' contributions}

JHL contributed to the study design, data collection, drafting of the manuscript, and statistical analysis. YIL contributed to the data collection and statistical analysis. JA contributed to the study design and statistical analysis. JAR contributed to the study conception and design, data collection, and drafting of the manuscript. All authors read and approved the final manuscript.

\section{Acknowledgments}

We would like to thank the nursing director of the neurosurgical intensive care unit, Hye Jung Kim, for her excellent advice and fruitful discussions. We also thank all nurses of the neurosurgical intensive care unit at Samsung Medical Center.

\section{References}

1. Ekeloef S, Alamili M, Devereaux PJ, Gogenur I. Troponin elevations after non-cardiac, non-vascular surgery are predictive of major adverse cardiac events and mortality: a systematic review and metaanalysis. Br J Anaesth. 2016;117:559-68. 
2. Devereaux PJ, Xavier D, Pogue J, Guyatt G, Sigamani A, Garutti I, Leslie K, Rao-Melacini P, Chrolavicius S, Yang H, Macdonald C, Avezum A, Lanthier L, Hu W, Yusuf S. Characteristics and short-term prognosis of perioperative myocardial infarction in patients undergoing noncardiac surgery: a cohort study. Ann Intern Med. 2011;154:523-8.

3. Devereaux PJ, Mrkobrada M, Sessler DI, Leslie K, Alonso-Coello P, Kurz A, Villar JC, Sigamani A, Biccard BM, Meyhoff CS, Parlow JL, Guyatt G, Robinson A, Garg AX, Rodseth RN, Botto F, Lurati Buse G, Xavier D, Chan MT, Tiboni M, Cook D, Kumar PA, Forget P, Malaga G, Fleischmann E, Amir M, Eikelboom J, Mizera R, Torres D, Wang CY, VanHelder T, Paniagua P, Berwanger O, Srinathan S, Graham M, Pasin L, Le Manach Y, Gao P, Pogue J, Whitlock R, Lamy A, Kearon C, Baigent C, Chow C, Pettit S, Chrolavicius S, Yusuf S. Aspirin in patients undergoing noncardiac surgery. N Engl J Med. 2014;370:1494-503.

4. Devereaux PJ, Chan MT, Alonso-Coello P, Walsh M, Berwanger O, Villar JC, Wang CY, Garutti RI, Jacka MJ, Sigamani A, Srinathan S, Biccard BM, Chow CK, Abraham V, Tiboni M, Pettit S, Szczeklik W, Lurati Buse G, Botto F, Guyatt G, Heels-Ansdell D, Sessler DI, Thorlund K, Garg AX, Mrkobrada M, Thomas S, Rodseth RN, Pearse RM, Thabane L, McQueen MJ, VanHelder T, Bhandari M, Bosch J, Kurz A, Polanczyk C, Malaga G, Nagele P, Le Manach Y, Leuwer M, Yusuf S. Association between postoperative troponin levels and 30-day mortality among patients undergoing noncardiac surgery. Jama. 2012;307:2295-304.

5. Lim W, Qushmaq I, Devereaux PJ, Heels-Ansdell D, Lauzier F, Ismaila AS, Crowther MA, Cook DJ. Elevated cardiac troponin measurements in critically ill patients. Arch Intern Med. 2006;166:2446-54.

6. Park J, Hyeon CW, Lee SH, Kim J, Kwon JH, Yang K, Min JJ, Lee JH, Lee SM, Yang JH, Song YB, Hahn JY, Choi JH, Choi SH, Kim K, Ahn J, Gwon HC. Mildly Elevated Cardiac Troponin below the 99thPercentile Upper Reference Limit after Noncardiac Surgery. Korean Circ J. 2020.

7. Ford I, Shah AS, Zhang R, McAllister DA, Strachan FE, Caslake M, Newby DE, Packard CJ, Mills NL. High-Sensitivity Cardiac Troponin, Statin Therapy, and Risk of Coronary Heart Disease. J Am Coll Cardiol. 2016;68:2719-28.

8. Omland T, de Lemos JA, Sabatine MS, Christophi CA, Rice MM, Jablonski KA, Tjora S, Domanski MJ, Gersh BJ, Rouleau JL, Pfeffer MA, Braunwald E. A sensitive cardiac troponin T assay in stable coronary artery disease. N Engl J Med. 2009;361:2538-47.

9. Garrett MC, Komotar RJ, Starke RM, Doshi D, Otten ML, Connolly ES. Elevated troponin levels are predictive of mortality in surgical intracerebral hemorrhage patients. Neurocrit Care. 2010;12:199203.

10. Connor RC. Myocardial damage secondary to brain lesions. Am Heart J. 1969;78:145-8.

11. Doshi R, Neil-Dwyer G. Hypothalamic and myocardial lesions after subarachnoid haemorrhage. J Neurol Neurosurg Psychiatry. 1977;40:821-6.

12. Zaroff JG, Rordorf GA, Ogilvy CS, Picard MH. Regional patterns of left ventricular systolic dysfunction after subarachnoid hemorrhage: evidence for neurally mediated cardiac injury. J Am Soc Echocardiogr. 2000;13:774-9. 
13. Naidech AM, Kreiter KT, Janjua N, Ostapkovich ND, Parra A, Commichau C, Fitzsimmons BF, Connolly ES, Mayer SA. Cardiac troponin elevation, cardiovascular morbidity, and outcome after subarachnoid hemorrhage. Circulation. 2005;112:2851-6.

14. Kristensen SD, Knuuti J. New ESC/ESA Guidelines on non-cardiac surgery: cardiovascular assessment and management. Eur Heart J. 2014;35:2344-5.

15. Oscarsson A, Fredrikson M, Sorliden M, Anskar S, Gupta A, Swahn E, Eintrei C. Predictors of cardiac events in high-risk patients undergoing emergency surgery. Acta Anaesthesiol Scand. 2009;53:98694.

16. Knaus WA, Draper EA, Wagner DP, Zimmerman JE. APACHE II: a severity of disease classification system. Crit Care Med. 1985;13:818-29.

17. Capuzzo M, Valpondi V, Sgarbi A, Bortolazzi S, Pavoni V, Gilli G, Candini G, Gritti G, Alvisi R. Validation of severity scoring systems SAPS II and APACHE II in a single-center population. Intensive Care Med. 2000;26:1779-85.

18. Meredith W, Rutledge R, Fakhry SM, Emery S, Kromhout-Schiro S. The conundrum of the Glasgow Coma Scale in intubated patients: a linear regression prediction of the Glasgow verbal score from the Glasgow eye and motor scores. J Trauma. 1998;44:839-44; discussion 44-5.

19. Austin PC. Optimal caliper widths for propensity-score matching when estimating differences in means and differences in proportions in observational studies. Pharm Stat. 2011;10:150-61.

20. Adams JE, 3rd, Abendschein DR, Jaffe AS. Biochemical markers of myocardial injury. Is MB creatine kinase the choice for the 1990s? Circulation. 1993;88:750-63.

21. Noordzij PG, van Geffen O, Dijkstra IM, Boerma D, Meinders AJ, Rettig TC, Eefting FD, van Loon D, van de Garde EM, van Dongen EP. High-sensitive cardiac troponin T measurements in prediction of noncardiac complications after major abdominal surgery. Br J Anaesth. 2015;114:909-18.

22. Rimaz S, Ashraf A, Marzban S, Haghighi M, Zia Ziabari SM, Biazar G, Rimaz S, Omidi S. Significance of Cardiac Troponin I Elevation in Traumatic Brain Injury Patients. Anesthesiology and pain medicine. 2019;9:e90858-e.

23. Chen Z, Venkat P, Seyfried D, Chopp M, Yan T, Chen J. Brain-Heart Interaction: Cardiac Complications After Stroke. Circ Res. 2017;121:451-68.

24. Todd GL, Baroldi G, Pieper GM, Clayton FC, Eliot RS. Experimental catecholamine-induced myocardial necrosis. I. Morphology, quantification and regional distribution of acute contraction band lesions. $J$ Mol Cell Cardiol. 1985;17:317-38.

\section{Figures}




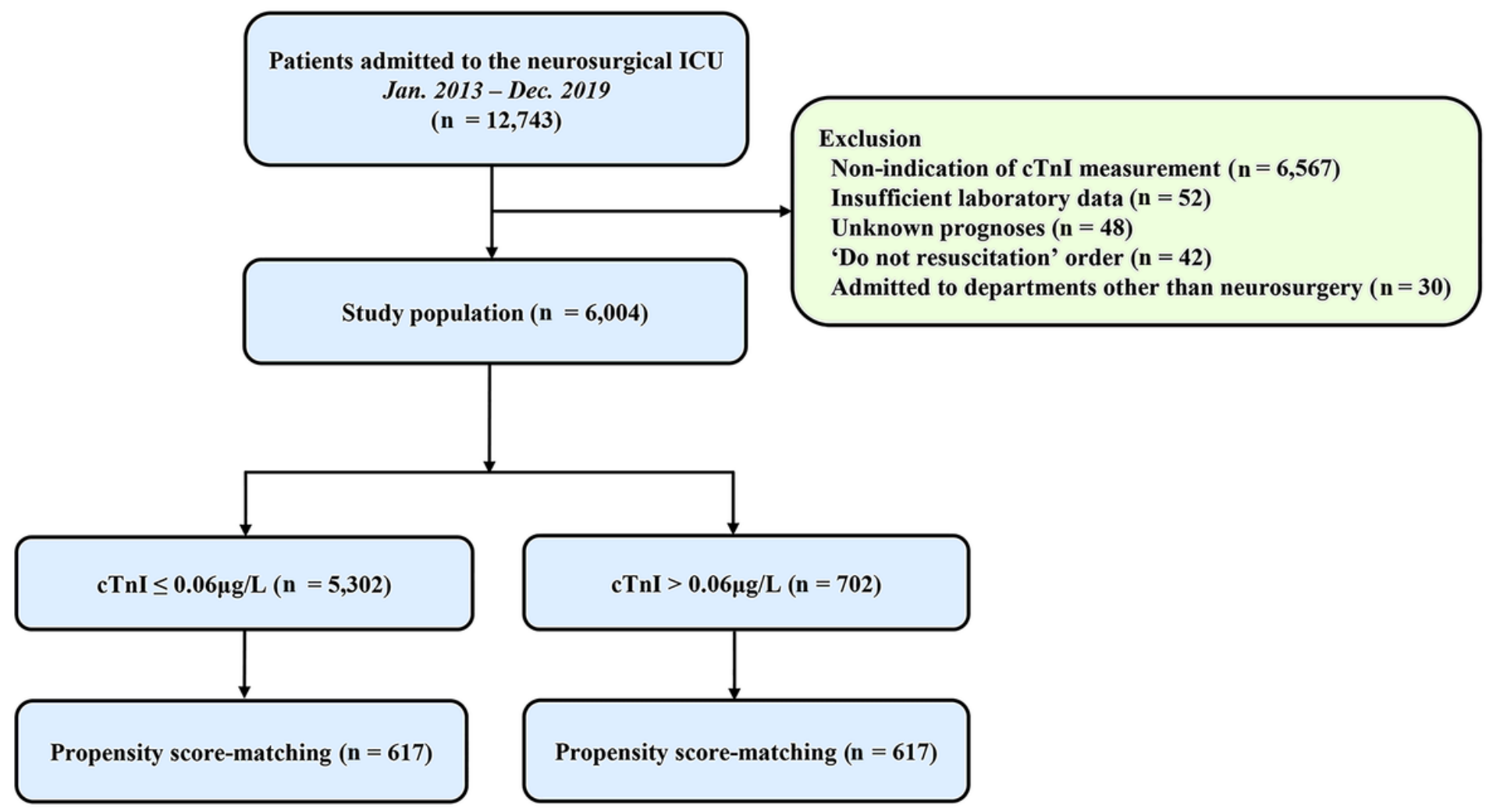

\section{Figure 1}

Study flow chart. ICU, intensive care unit; cTnl, cardiac troponin I 


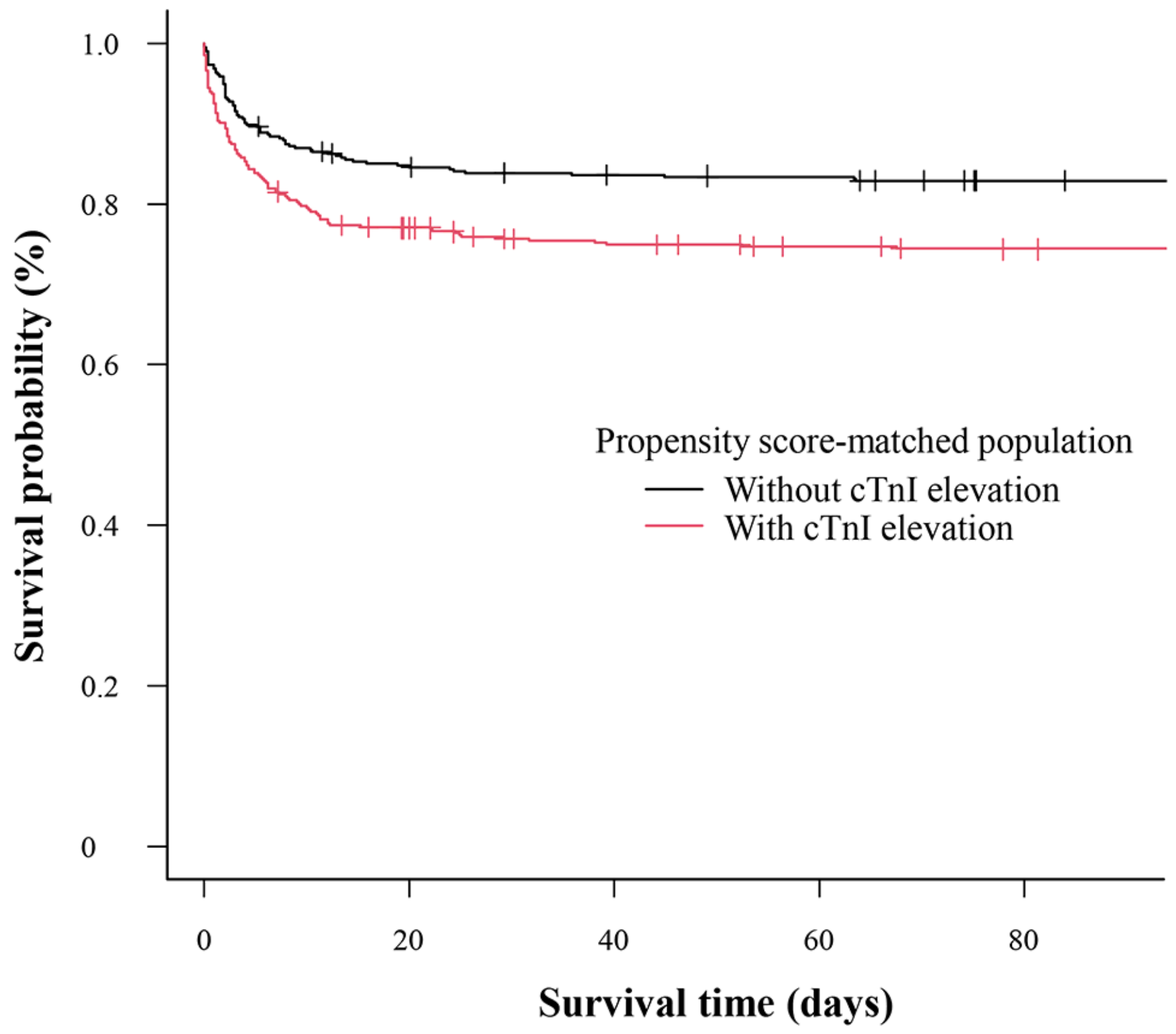

Figure 2

Kaplan Meier survival analyses of propensity score-mached population. The mortality rate of patients with cardiac troponin I (cTnl) elevation was significantly higher compared with those without cTnl elevation $(28.8 \%$ vs. $19.3 \%$, log-rank test, $p<0.001)$. 